\title{
HUBUNGAN ASUPAN ENERGY DENGAN STATUS GIZI ANAK PRA SEKOLAH USIA 4-5 TAHUN DI TK AL ISLAM JAMSAREN SURAKARTA
}

\author{
Anik Kurniawati ${ }^{1}$, Endang Suwanti ${ }^{2}$ \\ Poltekkes Kemenkes Surakarta Jurusan Kebidanan \\ Diterima : 4 Januari 2019, Disetujui : 4 Februari 2019
}

\begin{abstract}
Background: The nutritional status of children is influenced by two factors, namely the direct factor in food intake and infectious diseases and indirect causes. Nutritional factors are known to play an important role in determining the growth of a child. When experiencing growth, cells in the body need energy to divide, if energy requirements are not met, cell division will be inhibited and the effect will be seen through anthropometric and biochemical parameters. Objective, To determine the relationship between energy intake and nutritional status of preschoolers aged 4-5 years at Al Islam 1 Jamsaren Kindergarten in Surakarta. The research hypothesis, there is a relationship between energy intake and nutritional status of pre-school age children 4-5 years old at Al Islam Jamsaren Kindergarten in Surakarta. Method: This type of research is this study using a cross sectional approach. The target population in this study was the population in this study were all mothers and children aged 4-5 years in Al Islam 1 TK Jamsaren Surakarta totaling 89 people. Samples were taken by purposive technique with a sample of 47 respondents. Analysis of sperman rank test data. Results: Showed that the majority of respondents had a moderate energy intake of 17 (36.2\%) respondents and most had good nutritional status 38 (80.8\%) respondents. Conclusion: There is a relationship between energy intake and the nutritional status of pre-school children aged 4-5 years in Surakarta Jamsaren Kindergarten with p value 0.02.
\end{abstract}

Keywords: Energy Intake, Nutritional Status

\section{PENDAHULUAN}

Pertumbuhan dan perkembangan merupakan aspek terpenting dalam kehidupan seseorang karena menentukan dasar kehidupan selanjutnya (Susilaningrum, 2013). Fase terpenting dalam pertumbuhan dan perkembangan anak adalah ketika masa bayi dan balita, karena pada masa itulah saat yang paling vital bagi orang tua dalam membangun fondasi pertumbuhan dan perkembangan buah hati. Proses pertumbuhan dan perkembangan pada masa bayi dan balita merupakan proses yang teramat penting dalam menentukan masa depan anak baik secara fisik, mental maupun perilaku (Sunartyo, 2010).

Usia prasekolah dapat mempengaruhi dan menentukan tumbuh kembang anak selanjutnya (Wong, 2011). Masa prasekolah merupakan usia antara 3 sampai 6 tahun (Soetjiningsih, 2012). Pada masa ini orang tua dan keluarga diharapkan dapat memantau perumbuhan dan perkembangan anaknya, agar dapat dilakukan intervensi dini bila anak mengalami kelainan atau gangguan. Dengan ditemukan secara dini penyimpangan/ masalah tumbuh kembang anak, maka intervensi akan lebih mudah 
dilakukan, tenaga kesehatan juga mempunyi "waktu" dalam membuat intervensi yang tepat, terutama ketika harus melibatkan ibu/keluarga.

Data WHO menunjukkan bahwa kasus anak usia prasekolah underweight di dunia sebesar $15,7 \%$ dan anak usia prasekolah overweight sebanyak $6,6 \%$ (WHO, 2013). Berdasarkan laporan dari riset kesehatan dasar (RISKESDAS 2013) masalah gizi di Indonesia cukup tinggi yaitu $19,6 \%$ pada tahun 2013 dan di Provinsi Jawa Tengah sendiri angka prevalensi stunted (hambatan pertumbuhan) pada balita di Jawa Tengah adalah sebesar $24,5 \%$. Studi pendahuluan dilakukan penulis di TK Al Islam 1 Jamsaren, Surakarta pada tanggal 1 Maret 2018, didapatkan hasil bahwa sebanyak $23 \%$ dari 23 anak megalami gizi kurang.

Status gizi balita dipengaruhi oleh 2 faktor yaitu factor langsung berupa asupan makanan dan penyakit infeksi serta penyebab tidak langsung. Faktor nutrisi diketahui berperan penting dalam menentukan pertumbuhan seorang anak. Saat mengalami pertumbuhan, sel-sel dalam tubuh membutuhkan energi untuk membelah, apabila kebutuhan energi tidak terpenuhi, maka pembelahan sel akan terhambat dan efeknya akan terlihat melalui parameter antropometri maupun biokimia. Asupan nutrisi yang baik akan tercapai jika pola makan anakjuga baik, tercukupi seluruh unsur zat gizi. Jika pola makan tidak tercapai dengan baik pada anak usia prasekolah maka masa pertumbuhan akan terganggu. Sehingga dapat menyebabkan tubuh kurus, pendek, bahkan bisa terjadi gizi buruk pada anak usia prasekolah (Proverawati, 2009).

Menurut Kemenkes RI dalam Haryani (2010) pola makan yaitu makanan sehat dan mengandung zat gizi yang dikonsumsi secara teratur guna untuk memenuhi kebutuhan tubuh, yang tepat pemberiannya sehingga dapat melancarkan pertumbuhan dan perkembangan pada anak. Pola makan yang tidak bergizi pada anak usia sekolah dalam jangka waktu yang lama akan menyebabkan kurangnya gizi dalam tubuh.

Dari latar belakang tersebut, peneliti tertarik untuk melakukan studi kasus tentang "Hubungan antara asupan energy dengan status gizi Anak Usia Prasekolah Usia 4-5 Tahun di TK Al Islam 1 Jamsaren Surakarta".

\section{METODE PENELITIAN}

Penelitian ini menggunakan jenis penelitian observasional analitik menggunakan pendekatan cross sectional yang antara data input dan output dihasilkan pada kurun waktu yang bersamaan (Riyanto, 2011).

Penelitian ini dilakukan di TK Al Islam 1 Jamsaren, Surakarta. Waktu penelitian ini dilaksanakan pada bulan April-September 2018.

Populasi dalam penelitian ini adalah semua ibu dan anak usia 4-5 tahun di TK Al Islam 1 Jamsaren Surakarta berjumlah 89 orang..

Penelitian ini menggunakan teknik sampling yaitu purposive sampling, Besar sampel yang diambil adalah berjumlah 47 ibu dan anak usia 4-5 tahun di TK Al Islam 1 Jamsaren Surakarta dari rumus besar sampel (Notoatmojo, 2012)

Variabel Independan (bebas) pada penelitian ini yaitu asupan energy yang dilihat dari pola makan balita, Variabel Dependen (terikat) pada penelitian ini yaitu status gizianak usia 4-5 tahun, Instrumen yang digunakan dalam penelitian ini adalah berupa food record. 
Untuk mengetahui pertumbuhan digunakan timbangan dan meteran/metline serta tabel status gizi.

$\begin{array}{rrr}\text { Analisis univariate } & \text { dalam } \\ \text { penelitian ini } & \text { adalah untuk }\end{array}$ mengindentifikasi distribusi frekuensi mengenai pola makan dan pertumbuhan anak usia prasekolah usia 4-5 tahun.

Penelitian ini menggunakan analisis Uji Spearman Rank. Uji Spearman Rank

\section{HASIL PENELITIAN}

1. Gambaran pola makan anak usia prasekolah di TK Al Islam 1 Jamsaren, Surakarta

Tabel 1. Distribusi Frekuensi Pola Makan Anak Usia Prasekolah di TK Al Islam 1 Jamsaren, Surakarta

\begin{tabular}{lrr}
\hline $\begin{array}{l}\text { Pola Makan Anak } \\
\text { Usia Prasekolah } \\
\text { Usia 4-5 Tahun }\end{array}$ & Frekuensi & $\begin{array}{c}\text { Persentase } \\
(\%)\end{array}$ \\
\hline Defisit Tingkat & 6 & 12.7 \\
Berat & 17 & 36.2 \\
Defisit Tingkat & 10 & 21.3 \\
Sedang & 10 & 21.3 \\
Defisit Tingkat & 4 & 8.5 \\
Rendah & & \\
Normal & & \\
Diatas & & \\
AKG/Berlebih & & \\
\hline \multicolumn{1}{c}{ Jumlah } & 47 & \\
\hline Sumber :Data Prim & & \\
\hline
\end{tabular}

Sumber : Data Primer

Berdasarkan Tabel 1. diketahui bahwa pola makan anak usia prasekolah usia 4-5 tahun paling banyak mempunyai pola makan dengan asupan energy deficit tingkat sedang sebanyak 17 anak (36.2\%)

2. Gambaran status gizi anak usia prasekolah di TK Al Islam 1 Jamsaren, Surakarta
Tabel 2. Distribusi Frekuensi Status Gizi Anak Usia Prasekolah di TK Al Islam 1 Jamsaren, Surakarta

\begin{tabular}{lcc}
\hline $\begin{array}{c}\text { Status Gizi } \\
\text { Anak } \\
\text { Prasekolah }\end{array}$ & Frekuensi & $\begin{array}{c}\text { Persentase } \\
(\%)\end{array}$ \\
$\quad$ Usia 4-5 & & \\
$\quad$ Tahun & & 0 \\
\hline Buruk & 0 & 10.63 \\
Kurang & 5 & 80.85 \\
Baik & 38 & 8.52 \\
Lebih & 4 & \\
\hline \multicolumn{1}{c}{ Jumlah } & 47 & 100 \\
\hline
\end{tabular}

Sumber : Data Primer

Berdasarkan data primer tersebut dapat diketahui bahwa pertumbuhan anak usia prasekolah usia 4-5 tahun di TK Al Islam 1 Jamsaren, Surakarta sebagian besar memiliki pertumbuhan yang normal yaitu sebanyak 38 responden (80.85\%).

3. Hubungan antara asupan energy dengan status gizi anak usia prasekolah usia 4-5 tahun

Kedua data yang didapat kemudian di analisis dengan menggunakan rumus Spearman Rank untuk mengetahui apakah ada hubungan antara asupan energy dengan status gizi . Analisis data tersebut dilakukan dengan bantuan program SPSS versi 21. Berikut analisis data yang didapat:

Tabel 3. Hubungan Status Gizi dengan Siklus Menstruasi

\begin{tabular}{|c|c|c|c|c|c|c|c|}
\hline \multirow{2}{*}{ Asupan Gizi } & \multicolumn{3}{|c|}{ Status Gizi } & \multirow[b]{2}{*}{ Lebih } & \multirow{2}{*}{ Jmlh } & \multirow{2}{*}{ Sig. } & \multirow{2}{*}{$\mathrm{r}$} \\
\hline & Buruk & Kurang & Baik & & & & \\
\hline Defisit & 0 & 0 & 3 & 3 & 6 & 0.02 & 0,432 \\
\hline Tingkat Berat & 0 & 0 & 17 & 0 & 17 & & \\
\hline Defisit & 0 & 1 & 9 & 0 & 10 & & \\
\hline Tingkat & 0 & 3 & 7 & 0 & 10 & & \\
\hline Sedang & 0 & 1 & 2 & 1 & 4 & & \\
\hline Defisit & & & & & & & \\
\hline Tingkat & & & & & & & \\
\hline Rendah & & & & & & & \\
\hline Normal & & & & & & & \\
\hline Diatas AKG/ & & & & & & & \\
\hline Berlebih & & & & & & & \\
\hline Jumlah & 0 & 5 & 38 & 4 & & & \\
\hline
\end{tabular}


Pada hasil penelitian dapat diketahui bahwa nilai sig. 0,001. Keputusan uji Spearman Rank bahwa jika nilai sig. $<0.05$ maka Ha diterima, yang berarti terdapat hubungan antara asupan energy dengan status gizi anak usia prasekolah usia 4-5 tahun di TK Al Islam 1 Jamsaren Surakarta. Kriteria tingkat hubungan (correlation coefficient) antar variabel bernilai 0,432 maka berarti hubungan antar variabel tersebut adalah korelasi sedang.

\section{PEMBAHASAN}

Dari hasil penelitian dapat diketahui bahwa ada hubungan antara pola makan dan pertumbuhan anak usia prasekolah usia 4-5 tahun di TK Al Islam 1 Jamsaren Surakarta. Asupan energy anak diatas AKG/ berlebih 4 responden (8.5\%). Normal 10 responden 21.3\%). 10 responden dari 47 responden $(21.3 \%)$ mempunyai pola makan defisit tingkat rendah. 17 responden (36.2\%) mempunyai pola makan defisit tingkat sedang, dan 6 responden $(12.7 \%)$ mempunyai pola makan defisit tingkat berat. Sedangkan pertumbuhan anak usia prasekolah dalam kategori gemuk sebanyak 5 responden $(10,6 \%) .34$ responden dari 47 responden $(72,3 \%)$ mempunyai pertumbuhan normal, dan 8 responden $(17 \%)$ mempunyai pertumbuhan kurus.

Menurut Handjani dalam Sari (2012) mengemukakan pengertian pola makan yaitu tingkah laku manusia atau sekelompok manusia dalam memenuhi kebutuhan akan makanan yang meliputi sikap, kepercayaan. Dan pilihan makanan yang menggambarkan konsumsi makan harian meliputi jenis makanan, jumlah makanan, dan frekuensi makan. Pola makan seseorang dapat dipengaruhi oleh faktor ekonomi, sosio budaya, agama, pendidikan, dan lingkungan. Intake makanan perhari ditentukan sesuai penghitungan kalori perhari. Kebutuhan zat gizi pada anak memungkinkan pertumbuhan dan perkembangannya.

Pertumbuhan adalah bertambahnya ukuran dan jumlah sel serta jaringan intraseluler, berarti bertambahnya ukuran fisik dan struktur tubuh sebagian atau keseluruhan (Kemenkes, 2010). Pertumbuhan dipengaruhi oleh faktor genetik, nutrisi, lingkungan, hormon.

Dari hasil analisis Spearman Rank didapatkan nilai sig. $<0,05$ yaitu 0,002 maka dapat disimpulkan bahwa terdapat hubungan antara asupan gizi dari pola makan dan pertumbuhan anak usia prasekolah. Kriteria tingkat hubungan (correlation coefficient) antar variabel bernilai 0,432 maka berarti hubungan antar variabel tersebut adalah korelasi sedang. Hal ini sesuai dengan Sugianto (2015) bahwa faktor nutrisi diketahui berperan penting dalam menentukan pertumbuhan seorang anak. Saat mengalami pertumbuhan, sel-sel dalam tubuh membutuhkan energi untuk membelah, apabila kebutuhan energi tidak terpenuhi, maka pembelahan sel akan terhambat dan efeknya akan terlihat melalui parameter antropometri maupun biokimia.

Menurut Katarsapoetra dalam Hakim (2011) bahwa makanan yang bergizi berguna untuk memperoleh energi, energi tersebut digunakan untuk kegiatan fisik setiap hari dan proses tubuh untuk pertumbuhan dan perkembangan.

Hasil dari penelitian ini didukung oleh penelitian Kurniawati (2008) yang menunjukkan bahwa ada hubungan antara pola makan dengan status gizi balita. Balita dengan pola makan berlebih dengan status gizi baik sebanyak 17 balita, balita 
dengan pola makan normal dengan status gizi baik 5 balita dan kurang 7 balita, serta balita dengan pola makan defisit dengan status gizi kurang sebanyak 1 balita.

Anak usia prasekolah adalah mereka yang berusia 3-6 tahun (Monks et al. dalam Kurniawaty K, 2011). Pada usia ini kebutuhan gizinya yang semakin besar sejalan dengan perkembangan fisiknya harus diperhatikan. Sehingga pada masa ini penting bagi seorang ibu untuk memberikan perhatiannya, seperti halnya perawatan jasmani anak dalam bentuk pemberian gizi seimbang.

\section{KESIMPULAN DAN SARAN}

Berdasarkan hasil penelitian dan pembahasan yang telah diuraikan sebelumnya, dapat diambil kesimpulan sebagai berikut:

1. Sebagian besar anak usia prasekolah di TK Al Islam 1 Jamsaren Surakarta mempunyai asupan energy sedang yakni sebanyak 17 responden $(36,2 \%)$.

2. Status gizi anak usia prasekolah usia 4-5 tahun di TK Al Islam 1 Jamsaren mayoritas baik, yaitu sebanyak 38 responden $(80.8 \%)$.

3. Terdapat hubungan antara asupan energy dengan status gizi anak usia prasekolah usia 4-5 tahun di TK Al Islam 1 Jamsaren Surakarta dengan $\mathrm{p}$ value 0,02 .

4. Bagi tenaga kesehatan khususnya bidan diharapkan dapat lebih memberikan pendidikan kesehatan tentang gizi balita.

5. Bagi Orang Tua diharapkan orang tua harus memberikan makanan bergizi sesuai dengan kebutuhan anak

6. Bagi Penelitian Selanjutnya diharapkan penelitian selanjutnya lebih dapat memberi keterangan yang lebih jelas mengenai asupan gizi dengan variable lain.

\section{DAFTAR RUJUKAN}

Kurniawaty, dkk. Hubungan antara Pola Asuh Orang Tua dengan Perkembangan Anak Toddler (Usia 1-3 Tahun) di Kelurahan Bener Kecamatan Wiradesa Kabupaten Pekalongan. Skripsi. Stikes Muhammadiyah Pekajangan Pekalongan

Proverawati, Asfuah S. 2009. Buku Ajar Gizi untuk Kebidanan. Yogyakarta: Nuha Medika.

Riyanto, Agus. 2011. Aplikasi Metodologi Penelitian Kesehatan. Yogyakarta: Nuha Medika.

Sa'diya, L. 2015. Hubungan Pola Makan dengan Status Gizi Anak Pra Sekolah Di PAUD Tunas Mulia Claket Kecamatan Pacet Mojokerto. Skripsi.

Soetjiningsih. 2012. Tumbuh Kembang Anak. Jakarta: EGC.

Sugiyono. 2010. Metode penelitian kuantitatif, kualitatif, dan $r \& d$. Bandung: Alfabeta.

Sugiyono. 2013. Stastika untuk Penelitian. Bandung: Alfabeta.

Sunartyo. 2010. Pertumbuhan dan Perkembangan Anak. Jakarta: Rineka Cipta.

Susilaningrum, R. 2013. Asuhan Keperawatan Bayi dan Anak untuk Perawat dan Bidan. Jakarta: Salemba Medika.

Wong D.1., \& Huckenberry M.J. 2011. Wong's Nursing Care of Infants and Children, America. 